\title{
CX3CR1 deficiency suppresses activation and neurotoxicity of microglia/macrophage in experimental ischemic stroke
}

\author{
Zhiwei Tang ${ }^{1,3+}$, Yan Gan ${ }^{1 \dagger}$, Qiang Liu ${ }^{1,2}$, Jun-Xiang Yin ${ }^{1}$, Qingwei Liu' ${ }^{1}$, Jiong Shi ${ }^{1}$ and Fu-Dong Shi ${ }^{1,2^{*}}$
}

\begin{abstract}
Background: Chemokine (C-X3-C motif) ligand 1 (CX3CL1)/ CX3C chemokine receptor 1 (CX3CR1) signaling is important in modulating the communication between neurons and resident microglia/migrated macrophages in the central nervous system (CNS). Although CX3CR1 deficiency is associated with an improved outcome following ischemic brain injury, the mechanism of this observation is largely unknown. The aim of this study was to investigate how CX3CR1 deficiency influences microglia/macrophage functions in the context of its protection following brain ischemia.
\end{abstract}

Methods: Wild-type (WT) and CX3CR1-deficient $\left(\mathrm{CX}_{3} \mathrm{CR}^{-1-}\right)$ mice were subjected to transient middle cerebral artery occlusion (MCAO) and reperfusion. The ischemic brain damage was monitored by rodent high-field magnetic resonance imaging. Neurological deficit was assessed daily. Neuronal apoptotic death and reactive oxygen species (ROS) production were analyzed by immunostaining and live imaging. Activation/inflammatory response of microglia/macrophage were assessed using immunohistochemistry, flow cytometry, 5-bromo-2-deoxyuridine labeling, cytokine ELISA, and real-time PCR.

Results: $\mathrm{CX} 3 \mathrm{CR}_{1}{ }^{-/}$mice displayed significantly smaller infarcts and less severe neurological deficits compared to WT controls, following MCAO. In addition, CX3CR1 ${ }^{-1-}$ MCAO mice displayed fewer apoptotic neurons and reduced ROS levels. Impaired CX3CR1 signaling abrogated the recruitment of monocyte-derived macrophages from the periphery, suppressed the proliferation of CNS microglia and infiltrated macrophage, facilitated the alternative activation (M2 state) of microglia/macrophages, and attenuated their ability to synthesize and release inflammatory cytokines.

Conclusion: Our results suggest that inhibition of CX3CR1 signaling could function as a therapeutic modality in ischemic brain injury, by reducing recruitment of peripheral macrophages and expansion/activation of CNS microglia and macrophages, resulting in protection of neurological function.

Keywords: $\mathrm{CX} 3 \mathrm{CR} 1^{-/-}$, Microglia, Macrophage, Ischemic stroke, Middle cerebral artery occlusion

\section{Background}

Ischemic brain injury elicits an inflammatory response that involves activation of microglia and monocytederived macrophages in the central nervous system (CNS). Within the lesion, these cells adopt unique molecular phenotypes with either protective or detrimental

\footnotetext{
*Correspondence: Fu-Dong.Shi@dignityhealth.org

${ }^{\dagger}$ Equal contributors

'Department of Neurology and the BNI-ASU Center for Preclinical Imaging, Barrow Neurological Institute, St. Joseph's Hospital and Medical Center, 350 West Thomas Road, Phoenix, Arizona 85013, USA

${ }^{2}$ Department of Neurology, Key Laboratory of Neurorepair and Regeneration, Tianjin and Ministry of Education and Tianjin Neurological Institute, Tianjin Medical University General Hospital, Tianjin 300052, China

Full list of author information is available at the end of the article
}

effects on neuron survival [1]. Despite this basic understanding, the mechanisms controlling functional diversity in microglia/macrophages remain elusive but undoubtedly include differential signaling via chemokines, cytokines, and other cues present in the ischemic microenvironment.

The chemokine (C-X3-C motif) ligand 1 (CX3CL1)/ CX3C chemokine receptor 1 (CX3CR1) signaling pathway has been shown to play an important role in the maintenance of neural-immune communication in health and disease [2,3]. Fractalkine (CX3CL1), a membrane-bound chemokine, is expressed predominantly by neurons in the healthy CNS $[4,5]$ while its

\section{Biomed Central}


receptor (CX3CR1) is highly expressed on resident brain microglia and on peripheral immune cell populations including macrophages [6,7]. CX3CR1 selectively modulates microglia activity in response to its ligand CX3CL1 [6]. CX3CL1/CX3CR1 also regulates recruitment of circulating leukocytes to sites of injury $[8,9]$.

Under neuroinflammatory conditions, loss of signaling via CX3CR1 has been shown to have either protective $[10,11]$, or detrimental effects [12], or no effects at all $[13,14]$. These conflicting observations indicate the complexity and disease-specific regulation of neuron-microglia communication via CX3CL1 and CX3CR1. In regards to acute CNS injury models (transient and permanent brain ischemia, spinal cord injury), the collective data suggest that the absence of CX3CR1 significantly reduces ischemic damage and inflammation [15-17].

Although the processes of microglia activation, cytokine production, and phagocytosis have been studied in several animal models of ischemia injury in CX3CR1deficient $\left(\mathrm{CX} 3 \mathrm{CR} 1^{-/-}\right)$mice, it remains unclear as to how CX3CR1 deficiency alters the function of these cells, resulting in reduced damage during ischemic injury (highlighted by several controversial findings). Following induction of focal cerebral ischemia within $\mathrm{CX} 3 \mathrm{CR} 1^{-/-}$ mice, no difference was observed in the number of IL$1 \beta$-expressing microglia; rather, decreased leukocyte infiltration is involved in the development of smaller infarcts [15]. Conversely, in an animal model of spinal cord injury, modest but significantly more recruited monocytes $\left(\mathrm{CD} 45^{\mathrm{hi}}\right)$ accumulate in the spinal cord of $\mathrm{CX} 3 \mathrm{CR} 1^{-/-}$mice by 3 days post-injury [16]; however, a decrease in the number of $\mathrm{CD} 11 \mathrm{~b}^{+} / \mathrm{Ly}_{6} \mathrm{C}^{\mathrm{lo}} / \mathrm{iNOS}^{+}$macrophages after 7 days post-injury was associated with reduced neuropathology and enhanced functional recovery in these CX3CR1-deficient mice [16]. To date, little is known about the CX3CL1/CX3CR1 pathway in the context of microglia activation following brain ischemia.

In the current study, using a murine model of transient middle cerebral artery occlusion (MCAO), we tested the consequences of the absence of CX3CR1 on microglia/macrophage proliferation/recruitment and on their neurotoxicity after brain ischemia. We find that loss of CX3CR1 signaling attenuates the monocyte recruitment, the expansion of resident microglia and newly recruited monocytes, and reduced their inflammatory capacity after MCAO, contributing to neuroprotection in CX3CR1deficient mice.

\section{Materials and methods}

Animals

Breeding pairs of $\mathrm{CX} 3 \mathrm{CR} 1^{-/-}$mice were obtained from The Jackson Laboratory (Bar Harbor, ME, USA). Knockouts were generated by replacing the second exon of the
CX3CR1 gene with the enhanced green fluorescent protein (GFP) reporter gene, and backcrossed for more than 10 generations to C57BL/6 [13]. Cells under control of the endogenous CX3CR1 locus (that is, microglia, macrophages, dendritic cells, and so forth) in homozygote $\mathrm{CX} 3 \mathrm{CR} 1^{-1-}$ mice are labeled with GFP and also lack CX3CR1 receptor function. Wild-type (WT) C57BL/6 mice were purchased from Taconic (Oxnard, CA, USA). All animals were housed in pathogen-free conditions at the animal facilities of the Barrow Neurological Institute, Phoenix, AZ, USA. All experimental procedures were approved by the Institutional Animal Care and Use Committee of the Barrow Neurological Institute and performed according to the Revised Guide for the Care and Use of Laboratory Animals.

\section{Transient middle cerebral artery occlusion and reperfusion}

Adult male mice (aged 10 to 14 weeks, weight 24 to $27 \mathrm{~g}$ ) were exposed to transient (90 minutes) focal cerebral ischemia induced by occlusion of the right middle cerebral artery using an intraluminal filament method $[18,19]$. The production of an infarct was confirmed by 2,3,5-triphenyltetrazolium chloride (TTC) [20]. The methodology for MCAO and TTC staining is detailed in Additional file 1: Supplementary Methods.

\section{Neurological deficit assessment}

Daily neurological deficit assessment was performed by investigators blinded to the control and MCAO groups as described previously [19]. Rating scale: $0=$ no deficit, 1 = failure to extend left forepaw, 2 =decreased grip strength of left forepaw, 3 = circling to left by pulling the tail, and $4=$ spontaneous circling.

\section{Cerebral blood flow, apparent diffusion coefficient values, and T2-weighted images by rodent magnetic resonance imaging}

Magnetic resonance imaging (MRI) was performed on a 7-T small animal MRI, 30-cm horizontal-bore magnet, and BioSpec Avance III spectrometer (Bruker Daltonics Inc., Fremont, CA, USA). In order to assess whether the ischemia and reperfusion were induced successfully, single slice cerebral blood flow (CBF) images were acquired before $\mathrm{MCAO}, 1$ hour after MCAO and 24 hours after reperfusion, using a Continuous Arterial Spin Labeling sequence. Multiple Segments Echo Planer Imaging sequences were used to acquire apparent diffusion coefficient (ADC) values 30 minutes after MCAO to assess the damage volume. T2weighted images were acquired 24 and 72 hours after MCAO to evaluate the development of ischemic lesions, using a Rapid Acquisition with Refocused Echoes sequence. Detailed methodologies for these imaging are available in Additional file 1: Supplementary Methods. MRI data were 
analyzed using the MED $\times$ 3.4.3 software package (Medical Numerics Inc., Germantown, MA, USA) on a LINUX workstation.

\section{Reactive oxygen species assessment in vivo}

Reactive oxygen species (ROS) generated in the brain were assessed in live mice by using the Xenogen IVIS200 imager (Caliper Life Sciences, Alameda, CA, USA) [21]. Briefly, mice were intraperitoneally injected with $200 \mathrm{mg} / \mathrm{kg}$ Luminol (Invitrogen, Carlsbad, CA, USA). After $10 \mathrm{mi}-$ nutes, bioluminescence images were captured with exposure time of 3 minutes. A region of interest tool was used to measure the chemiluminescent intensity of the whole brain. Data were collected as photons per second per centimeter squared using the Living Image software (Caliper Life Sciences).

\section{Immunohistochemistry}

Terminally anesthetized mice were perfused intracardially with saline followed by $4 \%$ paraformaldehyde. The fixed brains were embedded in paraffin and cut into serial $6 \mu \mathrm{m}$ thick coronal slides. Immunohistochemistry was performed with antibodies against Iba-1 (Wako Chemicals USA Inc., Richmond, VA, USA) to identify macrophages and microglia; 4-hydroxy-2-nonenal (4-HNE; Abcam, Cambridge, MA, USA) and 8-hydroxy-2-deoxyguanosine (8-OHdG; Abcam) to identify lipid peroxidation and damaged DNA of oxidative impairment. Immunolabeling was detected by applying the peroxidase-antiperoxidase procedure with 3,3'-diaminobenzidine as a co-substrate. For double immunofluorescent staining, antibodies against NeuN (Millipore, Billerica, MA, USA) and cleaved Caspase-3 (Cell Signaling, Danvers, MA, USA) were used to identify apoptotic neurons. Respective negative controls that omit primary antibodies and positive controls were applied for each case. The positive cells were counted at $20 \times$ magnification in matched sections. Results are presented as Iba- $1^{+}, 4-\mathrm{HNE}^{+}, 8-\mathrm{OHdG}^{+}$or cleaved-Caspase$3^{+} / \mathrm{NeuN}^{+}$cells per $\mathrm{mm}^{2}$ within areas measured from $20 \times$ images using Image J.1.34vi software (National Institutes of Health) [12].

\section{Enzyme-linked immunosorbent assay}

Brain homogenates were prepared from WT and $\mathrm{CX} 3 \mathrm{CR} 1^{-1-}$ mice 72 hours after MCAO. Animals were anesthetized and the brains were removed and immediately frozen in liquid nitrogen. The ipsilateral or contralateral hemisphere was homogenized in RIPA buffer $(10 \mu \mathrm{l} / \mathrm{mg}$ brain, Sigma, St. Louis, MO, USA). Protein concentration was measured with bicinchoninic acid Protein Assay kit (Pierce, Appleton, WI, USA). The total protein concentration was adjusted to $1 \mathrm{mg} / \mathrm{ml}$ protein extract. The concentrations of IL-1 $\beta$, IL- 6 , and TNF- $\alpha$ in brain homogenates were quantified by enzyme-linked immunosorbent assay
(ELISA) kits (BioLegend, San Diego, CA, USA) and converted into $\mathrm{pg} / \mathrm{mg}$ protein extract.

\section{5-bromo-2-deoxyuridine labeling}

In order to visualize proliferating mononuclear cells in CNS, mice were injected intraperitoneally with 5bromo-2-deoxyuridine (BrdU) $(50 \mu \mathrm{g} / \mathrm{g}$ of mouse weight in saline, Sigma) immediately before the MCAO procedure and again 24, 48, and 60 hours after surgery. At 72 hours after surgery, mice were anesthetized with isoflurane and transcardially perfused with PBS. Brains were removed, and microglia and invading leukocyte isolation was performed according to the standardized protocol described below.

\section{Isolation of mononuclear cells from the central nervous system} The isolation of microglia and invading leukocytes are based on discontinuous percoll gradients [22-24]. Briefly, fresh brain tissues were removed from mice and cut into $\sim 2 \mathrm{~mm}$ pieces and incubated in $10 \mathrm{mM}$ Hepes/ $\mathrm{NaOH}$ buffer (10 mM HEPES, $150 \mathrm{mM} \mathrm{NaOH}, 7 \mathrm{mM}$ KCL, $1 \mathrm{mM}$ $\mathrm{MgCl}_{2}, 1 \mathrm{mM} \mathrm{MgCl} 2,0.36 \mathrm{mM} \mathrm{CaCl}$ ) containing $1 \mathrm{mg} / \mathrm{ml}$ collagenase (Sigma) for 1 hour at $37^{\circ} \mathrm{C}$. The tissues were dispersed with a syringe, filtered through a $100-\mathrm{mm}$ wire mesh, and centrifuged at 2,000 rpm for 5 minutes at $4^{\circ} \mathrm{C}$. After centrifugation, cell pellets were resuspended in $15 \mathrm{ml} 30 \%$ Percoll (Amersham Biosciences, Piscataway, NJ, USA), and centrifuged against 70\% Percoll in a 50-ml tube for $15 \mathrm{mi}-$ nutes. The cell monolayer at the 30 to $70 \%$ Percoll interface was collected and washed once for further staining.

\section{Flow cytometry}

\section{Cell phenotype}

The number of microglia/macrophage, their proliferation properties and inflammatory cytokine secretion were analyzed by flow cytometry. Single cell suspensions prepared from brain tissues were stained with fluorescently labeled antibodies: APC-CD45, PerCP-Cy5.5-CD45, PE-Ly6G, BV421-Ly6G, PE-Cy7-CD11b, PerCP-Cy5.5BrdU, PE-IL-1 $\beta$, V450-IL-6, or APC-TNF- $\alpha$ at designed combination. All antibodies and the isotype controls were purchased from BD Biosciences, San Jose, CA, USA. The staining was performed according to the manufacturer's instructions and the details are available in Additional file 1: Supplementary Methods. After staining, samples were analyzed using a FACSAria I flow cytometer (BD Biosciences). To avoid the interference of GFP expressed on CX3CR1 $1^{-/-}$ microglia/macrophage, fluors such as FITC and Alexafluor 488 that excite in the same spectrum at the same filter sets as GFP were excluded and the proper compensation was performed in flow cytometry. Subsequent data analyses were completed using FACSDiva software or FCS Express 4 software (BD Biosciences). 


\section{Cell sorting}

Microglia/macrophages were enriched from the single-cell suspension of the ischemic hemisphere of MCAO mice using CD11b MicroBeads (Miltenyi Biotec, Auburn, CA, USA), and then sorted via APC-45/PE-Cy7-CD11b/BV421Ly6G makers from the remaining cells by FACSAria I using Diva software (BD Biosciences). Purity of microglia and macrophages obtained by this approach reached $99 \%$.

\section{Quantitative real-time polymerase chain reaction analysis} Total RNA was extracted from the sorted microglia/ macrophages using the RNeasy Micro Kit (Qiagen, Germantown, MD, USA) according to the manufacturer's instructions; $1 \mu \mathrm{g}$ was used to synthesize the first strand of cDNA using the Superscript First-Strand Synthesis System for real-time PCR (Invitrogen). PCR was performed on the Opticon 2 Real-Time PCR Detection System (Bio-Rad, Hercules, CA, USA) using corresponding primers (Table 1) and $\mathrm{iQ}^{\mathrm{TM}}$ SYBR Green Supermix (Bio-Rad). Cycle conditions included heating for 5 minutes at $95^{\circ} \mathrm{C}$, followed by 40 cycles of 30 seconds at $95^{\circ} \mathrm{C}, 30$ seconds at $60^{\circ} \mathrm{C}$, and 60 seconds at $72^{\circ} \mathrm{C}$. A melt curve analysis was performed to ensure specific amplification. For each target gene, relative levels of expression were normalized against housekeeping gene GAPDH of the same sample. The relative expression levels of the mRNAs were then reported as fold changes versus sham controls.

\section{Statistical analysis}

Results are presented as the means \pm SEM. Statistical differences between two groups were evaluated by the twotailed unpaired Student's $t$-test. Multiple comparisons were performed with two-way analysis of variance

Table 1 Primer sets for murine genes

\begin{tabular}{|c|c|c|}
\hline Gene & Encoded protein & Primer \\
\hline \multirow[t]{2}{*}{ GAPDH } & \multirow[t]{2}{*}{$\begin{array}{l}\text { Glyceraldehyde-3-phosphate } \\
\text { dehydrogenase }\end{array}$} & $\begin{array}{l}\text { Forward: 5'- TGATGACATC } \\
\text { AAGAAGGTGGTGAAG -3' }\end{array}$ \\
\hline & & $\begin{array}{l}\text { Reverse 5'- TCCTTGGAGG } \\
\text { CCATGTAGGCCAT-3' }\end{array}$ \\
\hline \multicolumn{3}{|l|}{ M1 } \\
\hline \multirow[t]{2}{*}{ iNOS } & \multirow[t]{2}{*}{$\begin{array}{l}\text { Nitric oxide synthase, } \\
\text { inducible (iNOS) }\end{array}$} & $\begin{array}{l}\text { Forward: 5'-CCCTTCAATGG } \\
\text { TTGGTACATGG-3' }\end{array}$ \\
\hline & & $\begin{array}{l}\text { Reverse: 5'-ACATTGATCTCC } \\
\text { GTGACAGCC-3' }\end{array}$ \\
\hline \multicolumn{3}{|l|}{ M2 } \\
\hline \multirow[t]{2}{*}{ Mrc1 } & \multirow{2}{*}{$\begin{array}{l}\text { Mannose receptor, C type } 1 \\
\text { (MRC1), Macrophage mannose } \\
\text { receptor } 1 \text { (MMR), CD206 }\end{array}$} & $\begin{array}{l}\text { Forward: 5'-TCTाTGCCTITC } \\
\text { CCAGTCTCC-3' }\end{array}$ \\
\hline & & $\begin{array}{l}\text { Reverse: 5'-TGACACCCAGCG } \\
\text { GAATITC-3' }\end{array}$ \\
\hline \multirow[t]{2}{*}{$Y m 1$} & \multirow{2}{*}{$\begin{array}{l}\text { T-lymphocyte-derived } \\
\text { eosinophil chemotactic } \\
\text { factor (FCF-L) }\end{array}$} & $\begin{array}{l}\text { Forward: 5'-GGGCATACC } 11 \\
\text { ATCCTGAG-3' }\end{array}$ \\
\hline & & $\begin{array}{l}\text { Reverse: } 5^{\prime}-C C A C T G A A G T C A \\
\text { TCCATGTC-3' }\end{array}$ \\
\hline
\end{tabular}

accompanied by Bonferroni post-hoc test. Values of $P<$ 0.05 were considered significant.

\section{Results}

Reduction of infarct volume and neurological deficit by CX3CR1 deficiency after middle cerebral artery occlusion

To ensure the success of the MCAO model, CBF of right middle cerebral artery territory was examined at 24 hours before MCAO, and 1 hour and 24 hours following MCAO using high-field MRI. Animals wherein ischemia and reperfusion were induced successfully were selected for further analysis (Additional file 1: Figure S1A). No significant difference in CBF at baseline (WT, 171.3 \pm 9.5 vs $\left.\mathrm{CX} 3 \mathrm{CR} 1^{-/-}, 174.2 \pm 10.1 \mathrm{ml} / 100 \mathrm{~g} / \mathrm{min}, P>0.05\right)$, ischemia (WT, $33.5 \pm 14.3$ vs CX3CR1 ${ }^{-/-}, 31.2 \pm 13.1 \mathrm{ml} /$ $100 \mathrm{~g} / \mathrm{min}, P>0.05$ ) and reperfusion (WT, $160.1 \pm 15.1$ vs $\left.\mathrm{CX} 3 \mathrm{CR}^{-/-}, 155 \pm 12.3 \mathrm{ml} / 100 \mathrm{~g} / \mathrm{min}, P>0.05\right)$ was observed between WT and CX3CR $1^{-/-}$mice. Furthermore, ADC (measuring the magnitude of diffusion of water molecules within cerebral tissue) was acquired 30 minutes after MCAO to assess the damage volume of ipsilateral hemisphere (Additional file 1: Figure S1B, low value on the left). No significant differences in damage volume were observed between CX3CR1 ${ }^{-/-}$and WT mice (WT, $122.2 \pm 8.3 \mathrm{~mm}^{3} ; \mathrm{CX} 3 \mathrm{CR}^{-/-}, 119.1 \pm 6.7 \mathrm{~mm}^{3}$ ) (Additional file 1: Figure $\mathrm{S} 1 \mathrm{C}$ ).

To assess the infarct volume, T2-weighted images were acquired at 24 and 72 hours following MCAO. The infarct volume in WT mice was $36.5 \pm 5.7 \mathrm{~mm}^{3}$ at 24 hours and increased to $45.8 \pm 6.8 \mathrm{~mm}^{3}$ at 72 hours. Within $\mathrm{CX} 3 \mathrm{CR}^{-1-}$ mice, infarct volume was $26.9 \pm$ $5.7 \mathrm{~mm}^{3}$ at 24 hours, and a modest but significant decrease (to $19.0 \pm 4.9 \mathrm{~mm}^{3}$ ) was observed at 72 hours (Figure 1A). Although there was no significant difference in infarct volume at 24 hours between the two groups, CX3CR1 $1^{-/-}$mice showed markedly smaller infarct volume at 72 hours relative to WT mice $(P<0.01$, Figure $1 \mathrm{~B})$. The infarct observed in MRI scan was confirmed by TTC staining (Additional file 1: Figure S1D).

To further assess the differential response to $\mathrm{MCAO}$ in $\mathrm{CX} 3 \mathrm{CR} 1^{-/-}$and WT mice, the neurological deficit was assessed daily following MCAO. WT mice had an average clinical score of $2.4 \pm 0.4$ at 24 hours and $2.0 \pm$ 0.3 at 72 hours, while $\mathrm{CX} 3 \mathrm{CR} 1^{-/-}$mice had clinical scores of $2.0 \pm 0.3$ at 24 hours and $1.2 \pm 0.2$ at 72 hours indicative of the beginning of recovery at 72 hours in $\mathrm{CX} 3 \mathrm{CR} 1^{-/-}$mice but not in WT mice (Figure $1 \mathrm{C}$ ).

\section{CX3CR1 deficiency attenuates neuronal apoptosis after middle cerebral artery occlusion}

Double staining with NeuN (neuron marker) and cleaved Caspase-3 (apoptotic marker) was performed to investigate whether CX3CR1-dependent differences observed 

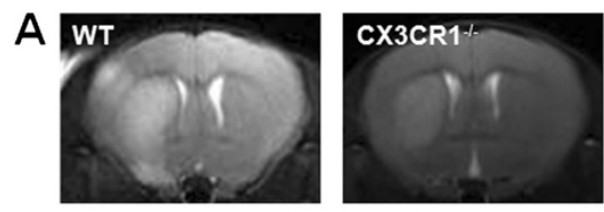

$24 \mathrm{~h}$

B

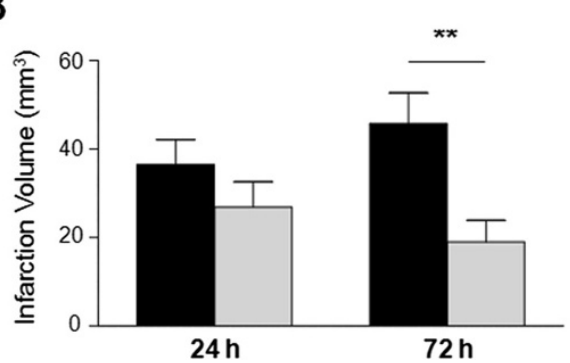

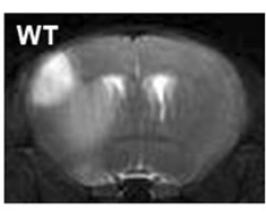

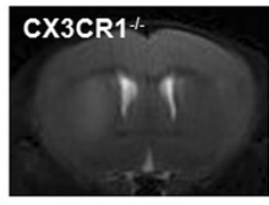

$72 \mathrm{~h}$

C

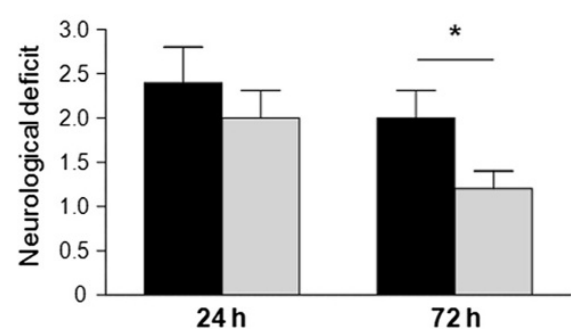

Figure 1 CX3CR1 deficiency attenuates infarct volume and neurological deficit after middle cerebral artery occlusion. (A) Infarct volume was assessed by T2-weighted images at 24 and 72 hours post-ischemia. (B) Quantification of T2 images shows that the infarct volume was attenuated by CX3CR1 deficiency 72 hours after middle cerebral artery occlusion (MCAO). $P<0.0001$ for genotype, $P=0.0194$ for time point, and $P=0.0011$ for interaction by two-way analysis of variance. ${ }^{*} P<0.01$ by Bonferroni post-hoc tests. (C) Clinical assessment demonstrated that CX3CR1 ${ }^{-1-}$ mice have better neurological deficit scores than wild-type (WT) mice 72 hours after MCAO. $P=0.0049$ for genotype, $P=0.0262$ for time point, and $P=0.0062$ for interaction by two-way analysis of variance. ${ }^{*} P<0.05$ by Bonferroni post-hoc tests. $n=6$ per group.

in the size of ischemic damage at 72 hours following $\mathrm{MCAO}$ were associated with differential neuronal apoptosis in peri-infarct areas. More cleaved Caspase-3 positive cells were observed in WT mice compared to CX3CR1 $1^{-1-}$ mice and co-localized with NeuN in most apoptotic cells (Figure 2A). The number of cleaved Caspase-3 positive neurons was $179.3 \pm 15.6 / \mathrm{mm}^{2}$ in WT mice and $95.1 \pm 16.9 / \mathrm{mm}^{2}$ in $\mathrm{CX} 3 \mathrm{CR} 1^{-/-}$mice 72 hours after MCAO $(P<0.01$, Figure $2 \mathrm{~B})$. To reveal the phenotype of the other apoptotic cells, double staining of cleaved Caspase- 3 with Iba-1 or GFAP markers, respectively, were employed. These experiments revealed cleaved Caspase-3 positive staining within some microglia and astrocytes (data not shown).
Fewer microglia and macrophages in ipsilateral hemisphere of $\mathrm{CX} 3 \mathrm{CR} 1^{-/-}$mice after middle cerebral artery occlusion

Microglia activation plays an important role in the pathological progression after stroke, and is regulated by CX3CR1 [6,12]. To investigate the effects of CX3CR1 deficiency upon these processes, expression of microglia/ macrophage activation marker Iba-1 was examined at different sites of the brain in $\mathrm{WT}$ and $\mathrm{CX} 3 \mathrm{CR} 1^{-/-}$mice 72 hours following MCAO (Figure 3A). In the ipsilateral hemisphere of WT mice, the numbers of Iba-1 positive cells in hippocampus, striatum, cortex and peri-infract area $\left(666.1 \pm 50.0,1132.8 \pm 96.1,730.9 \pm 68.1,489.4 \pm 56.1 / \mathrm{mm}^{2}\right)$ were significantly higher than those in $\mathrm{CX} 3 \mathrm{CR} 1^{-/-}$mice
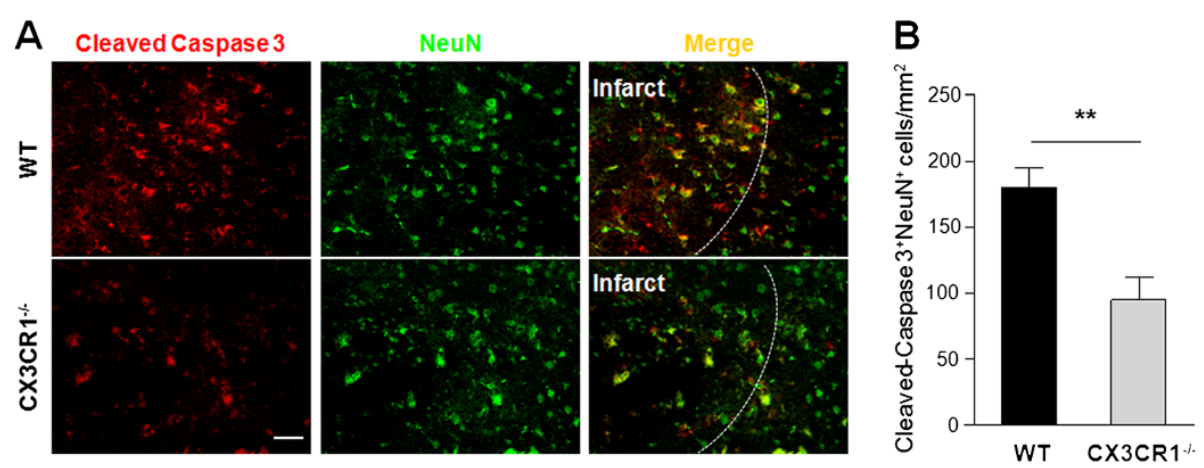

Figure 2 CX3CR1 deficiency attenuates neuronal apoptosis after middle cerebral artery occlusion. (A) Double staining with cleaved Caspase 3 (red) and NeuN (green) antibodies in peri-infarct area of wild-type (WT) and CX3CR1 ${ }^{-/-}$mice 72 hours after middle cerebral artery occlusion. (B) Quantification of Cleaved-Caspase 3/NeuN positive cells. CX3CR1 $1^{-1-}$ mice have fewer Cleaved-Caspase $3^{+} \mathrm{NeuN}^{+}$cells in the peri-infarct zone. ${ }^{* *} P<0.01$ by Student's $t$-test. $n=4$ per group. Scale bars $=50 \mu \mathrm{m}$. 


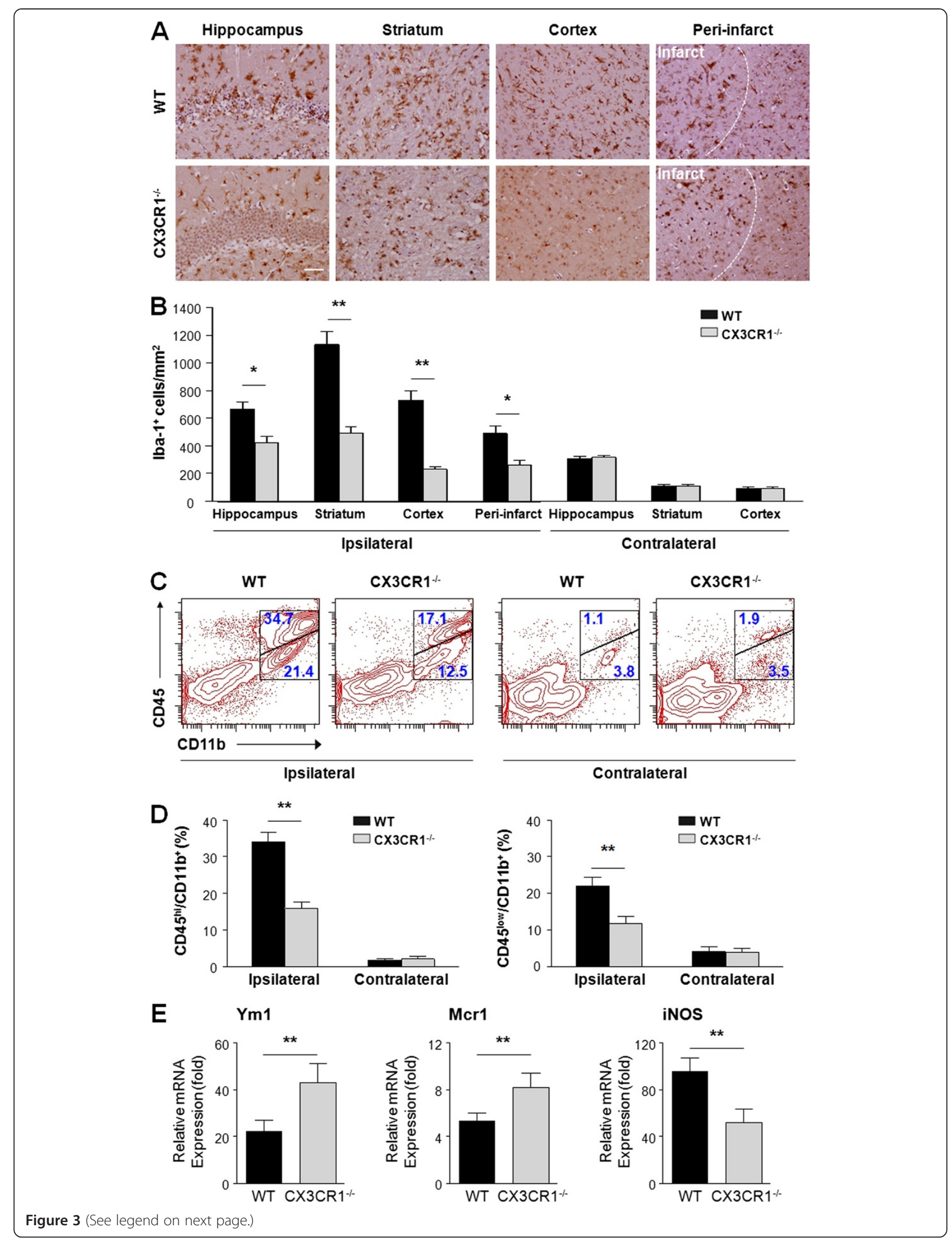




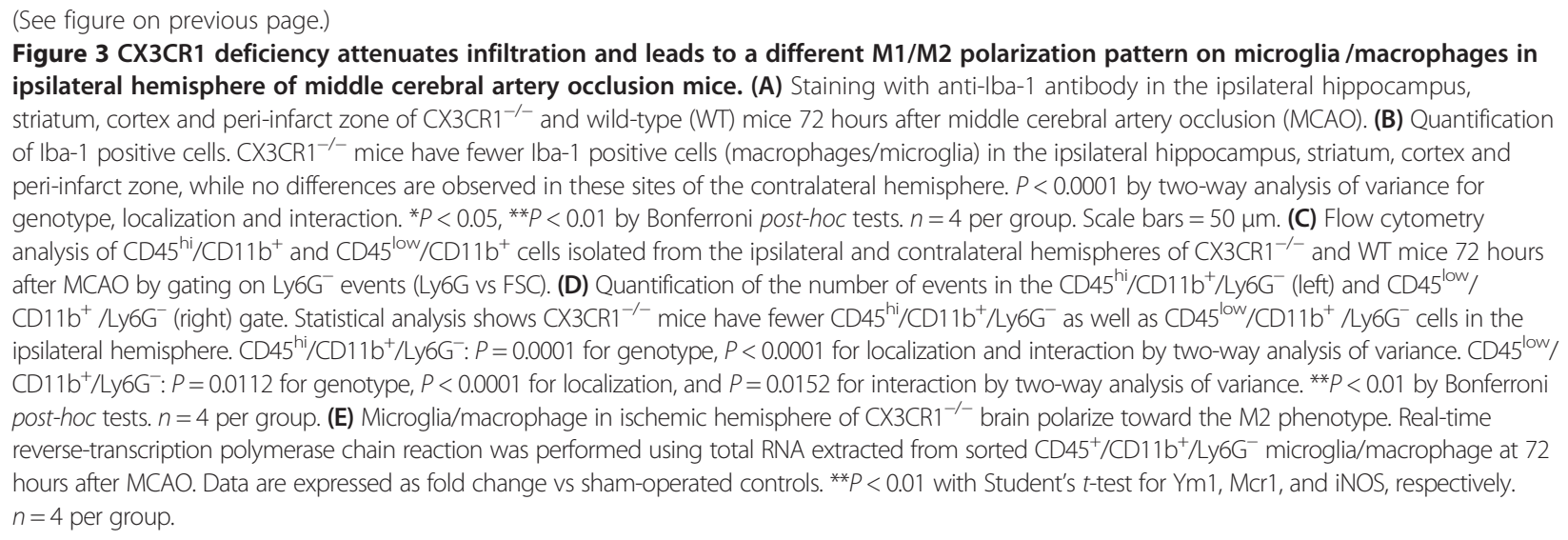

$\left(424.6 \pm 43.1,492.7 \pm 42.3,230.1 \pm 20.1,262.5 \pm 29.8 / \mathrm{mm}^{2}\right)$ (Figure $3 \mathrm{~B}$ ). In the contralateral hemisphere, the numbers of Iba-1 positive cells in the hippocampus, striatum and cortex were similar $(307.9 \pm 15.5$ vs $316.0 \pm 14.6,110.2 \pm$ 11.5 vs $111.8 \pm 9.7,94.0 \pm 8.6$ vs $92.4 \pm 13.1$, WT vs $\mathrm{CX} 3 \mathrm{CR}^{-/-}$) regardless of genotype (Figure $3 \mathrm{~B}$ ).

To further distinguish microglia from macrophages within the Iba- 1 positive cell population, flow cytometry was used to delineate $\mathrm{CD} 45^{\text {low }} / \mathrm{CD} 11 \mathrm{~b}^{+} / \mathrm{Ly}_{6 G^{-}}$(microglia) and $\mathrm{CD} 45^{\mathrm{hi}} / \mathrm{CD}_{11 \mathrm{~b}^{+}} / \mathrm{Ly}_{6 \mathrm{G}}{ }^{-}$(macrophage/activated microglia) sub-populations within ischemic lesions of WT and CX3CR1 ${ }^{-/-}$mice. As shown in Figure $3 \mathrm{C}, \mathrm{D}$, more macrophages/activated microglia infiltrated in the ischemia lesions in WT mice compared to $\mathrm{CX} 3 \mathrm{CR} 1^{-/-}$mice $(34.1 \pm$ $2.5 \%$ vs $15.9 \pm 1.8 \%)$. In addition, WT mice displayed more $\mathrm{CD}_{4} 5^{\text {low }}$ microglia than $\mathrm{CX} 3 \mathrm{CR} 1^{-/-}$mice $(22.1 \pm 2.3 \%$ vs $11.7 \pm 2.1 \%$, Figure $3 C, D)$. Both cell populations were similar in WT and CX3CR1 ${ }^{-1-}$ mice in the control (non-ischemic) contralateral hemisphere (Figure 3C,D).

Following ischemia, activated microglia/macrophage can potentially exert either a protective or detrimental effect, suggesting that these cells may acquire different phenotypes belonging to the classical (M1) or to the alternative (M2) active status. We found that activated M1-like Iba- $1^{+}$cells, which have shorter and thicker processes and bigger cell bodies, were visualized in the WT brain section, while ramified M2-like Iba- $1^{+}$cells were predominantly located in the $\mathrm{CX} 3 \mathrm{CR} 1^{-/-}$brain (Figure 3A). To evaluate their M1/M2 polarization, we sorted and purified microglia/macrophages

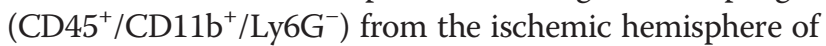
$\mathrm{CX} 3 \mathrm{CR} 1^{-/-}$and WT MCAO mice brain. Using real-time PCR, we found that the levels of tested M1- and M2-type genes in Fluorescence Activated Cell Sorter (FACS)-sorted microglia/macrophages from WT mice were increased starting from 1 day after MCAO and further elevated by 3 days post-MCAO (data not shown). Within CX3CR1 ${ }^{-/-}$ microglia/macrophages, the M2-type genes (Ym1, Mcr1) were significantly increased, whereas the M1-type gene
(iNOS) was notably decreased compared to WT microglia/ macrophages when isolated at 72 hours after MCAO (Figure 3E). These results suggest that deficiency of CX3CR1 may facilitate the alternative activation (M2 state) of microglia/macrophages in stroke.

\section{Reduced proliferation of macrophages and microglia in ipsilateral hemisphere of $\mathrm{CX} 3 \mathrm{CR}^{-/-}$mice after middle cerebral artery occlusion}

To determine whether the decrease in $\mathrm{CD}_{11 \mathrm{~b}^{+} \mathrm{Ly}_{6 \mathrm{G}}{ }^{-}}$ cells observed in ischemic lesions of CX3CR $1^{-1-} \mathrm{MCAO}$ mice, in addition to decreased chemotaxis of monocytes, was due to suppressed expansion of microglia/macro-

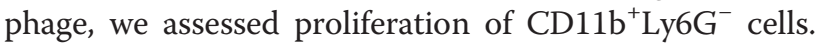
Proliferation analysis was performed on populations of CD $45^{\text {low }} / \mathrm{CD} 11 \mathrm{~b}^{+} / \mathrm{Ly}_{6 \mathrm{G}}{ }^{-}$cells (microglia), and CD $45^{\mathrm{hi}} /$ $\mathrm{CD}_{11 b^{+} / \mathrm{Ly} 6 \mathrm{G}^{-}}$cells (macrophage/activated microglia) obtained from $\mathrm{CX} 3 \mathrm{CR} 1^{-/-}$and WT mice injected with BrdU (Figure 4A). Quantitative analysis revealed a significant 3-fold increase in the number of $\mathrm{CD} 45^{\mathrm{low}}$ / $\mathrm{CD}_{11 \mathrm{~b}}{ }^{+} / \mathrm{Ly} 6 \mathrm{G}^{-} / \mathrm{BrdU}^{+}$cells in the ipsilateral relative to the contralateral hemisphere in WT mice 72 hours after stroke (Figure 4B). A significant reduction (71.1\%) in the number of proliferating $\mathrm{CD} 45^{\text {low }} / \mathrm{CD} 11 \mathrm{~b}^{+} / \mathrm{Ly} 6 \mathrm{G}^{-}$cells was observed in the ipsilateral hemisphere in CX3CR1 $1^{-/-}$compared to WT mice (WT, $43.3 \pm 4.1 \%$; $C X 3 C R 1^{-1-}, 12.5 \pm$ $2.2 \%, P<0.01$, Figure $4 \mathrm{~B})$. There were no significant differences in the numbers of $\mathrm{CD} 45^{\text {low }} / \mathrm{CD} 11 \mathrm{~b}^{+} / \mathrm{Ly} 6 \mathrm{G}^{-} / \mathrm{BrdU}^{+}$ cells in the contralateral hemisphere between the two experimental groups, although CX3CR $1^{-1-}$ mice showed a lesser trend (WT, $11.5 \pm 2.9 \%$; $\mathrm{CX} \mathrm{CR} 1^{-1-}, 6.7 \pm 0.7 \%$, $P>0.05$, Figure 4B). We also observed a modest but significant reduction (23.2\%) in the number of proliferating $\mathrm{CD} 5^{\mathrm{hi}} / \mathrm{CD} 11 \mathrm{~b}^{+} / \mathrm{Ly} 6 \mathrm{G}^{-}$cells in the ipsilateral hemisphere in CX3CR1 $1^{-1-}$ compared with WT mice (WT, $42.1 \pm 2.7 \%$; $\left.\mathrm{CX} 3 \mathrm{CR} 1^{-/-}, 32.3 \pm 3.9 \%, P<0.05\right)$. Collectively, these results indicate that CX3CR1 deficiency affects ischemic injury-induced proliferation of resident microglia and recruited macrophages. 


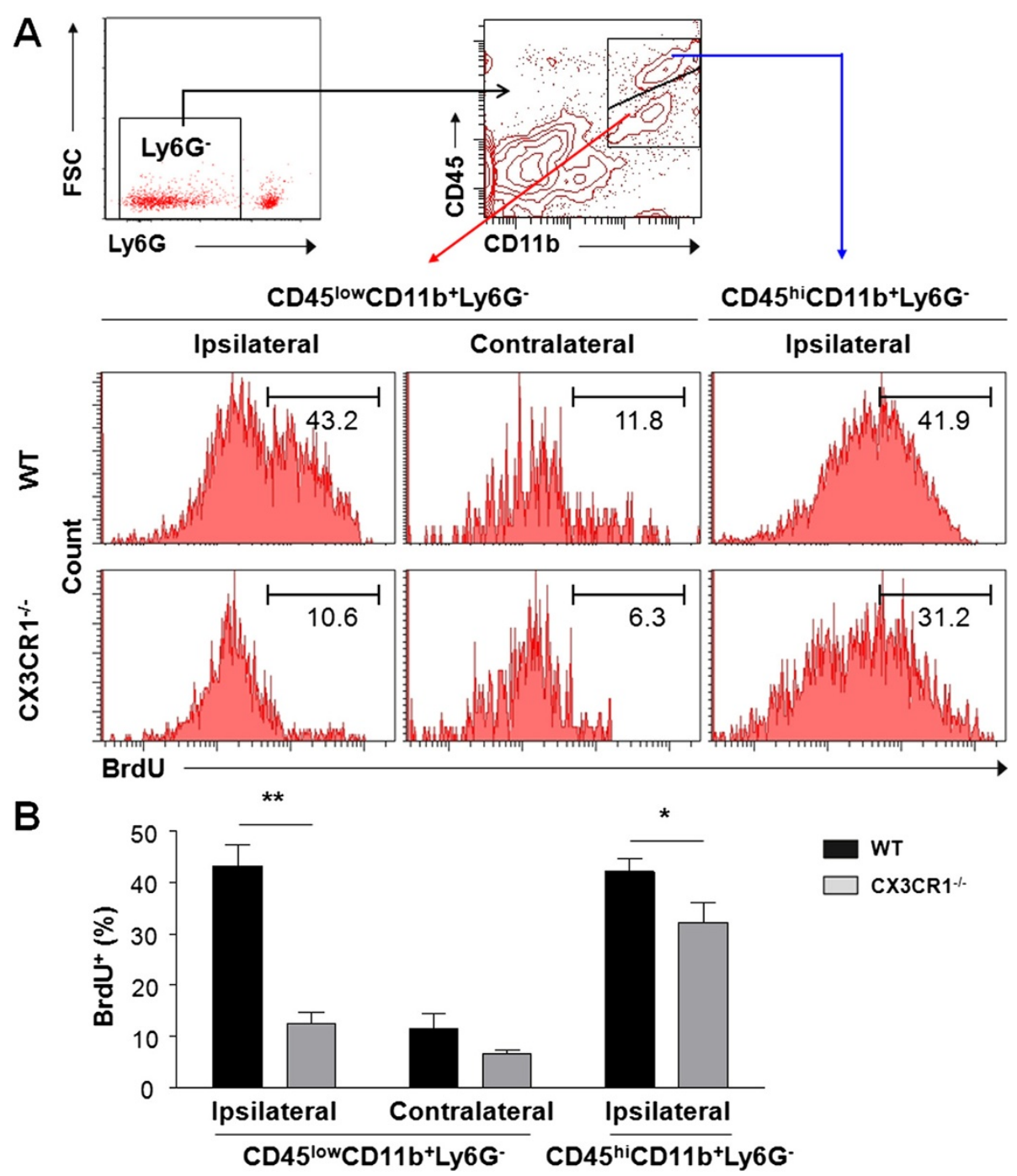

Figure 4 Suppressed proliferation of $\mathrm{CD} 45^{\text {low }} / \mathrm{CD} 11 \mathrm{~b}^{+} / \mathrm{Ly} 6 \mathrm{G}^{-}$and $\mathrm{CD} 45^{\mathrm{hi}} / \mathrm{CD} 11 \mathrm{~b}^{+} / \mathrm{Ly} 6 \mathrm{G}^{-}$cells in the ipsilateral hemisphere of CX3CR1 ${ }^{-1-}$ mice after middle cerebral artery occlusion. (A) Flow cytometry analysis of proliferation of Ly6 $\mathrm{G}^{-}$gated $\mathrm{CD} 45^{\text {low }} / \mathrm{CD} 11 \mathrm{~b}^{+}$(microglia) and $\mathrm{CD} 45^{\text {hi }} / \mathrm{CD} 11 \mathrm{~b}^{+}$(macrophages/activated microglia) population with 5-bromo-2-deoxyuridine (BrdU) incorporation in the ipsilateral hemisphere of wild-type (WT) and CX3CR1 ${ }^{-1-}$ mice 72 hours after middle cerebral artery occlusion (MCAO), compared to their contralateral (unlesioned) hemisphere controls. CD45 hi $/ \mathrm{CD} 11 \mathrm{~b}^{+} / \mathrm{Ly}_{6 \mathrm{G}}$ cell proliferation was not shown in the contralateral due to their very low to undetectable presence. (B) Graph presents quantification of microglia/macrophage proliferation measured by flow cytometry. Data indicate a marked reduction in $\mathrm{CD} 5^{\mathrm{low}} / \mathrm{CD} 11 \mathrm{~b}^{+} / \mathrm{Ly} 6 \mathrm{G}^{-}$ cell proliferation and a modest but significant reduction in $\mathrm{CD} 45^{\text {hi }} / \mathrm{CD} 11 \mathrm{~b}^{+} / \mathrm{Ly} 6 \mathrm{G}^{-}$cell proliferation in the ipsilateral hemisphere of $\mathrm{CX} 3 \mathrm{CR} 1^{-/-}$mice compared to WT mice 72 hours after MCAO. $P<0.0001$ for genotype and localization, $P=0.0017$ for interaction by two-way analysis of variance. ${ }^{*} P<0.05,{ }^{*} P<0.01$ by Bonferroni post-hoc tests. $n=4$ per group.

CX3CR1 deficiency attenuates reactive oxygen species generation in brain after middle cerebral artery occlusion ROS, generated as by-products of cellular metabolism, have long been known to be a component of the inflammatory response after ischemia. To investigate whether CX3CR1 deficiency had effects upon ROS production, we assessed ROS levels in live mice using the Xenogen IVIS200 imager at 24 and 72 hours after MCAO. The chemiluminescence detection of ROS was performed in the brains, specifically in the ipsilateral hemisphere (Figure 5A). The mean chemiluminescence intensity of brain in WT mice was $1,090.3 \pm$
$127.4 \mathrm{p} / \mathrm{s} / \mathrm{cm}^{2} / \mathrm{sr}$ (photons per second per centimeter squared per steradian) at 24 hours and $850.9 \pm 81.7 \mathrm{p} / \mathrm{s} /$ $\mathrm{cm}^{2} / \mathrm{sr}$ at 72 hours. Within CX3CR1 $1^{-1-}$ mice, mean chemiluminescence intensity values were $1,350.9 \pm 118.9 \mathrm{p} / \mathrm{s} /$ $\mathrm{cm}^{2} / \mathrm{sr}$ at 24 hours and $641.7 \pm 47.6 \mathrm{p} / \mathrm{s} / \mathrm{cm}^{2} / \mathrm{sr}$ at 72 hours. At 24 hours post-ischemia, no differences in ROS levels were observed between the two groups $(P>0.05)$. At 72 hours post-ischemia, the ROS levels decreased significantly in CX3CR1 $1^{-/-}$mice compared to 24 hours $(P<0.01)$, while no change was observed in WT mice $(P>0.05)$ (Figure $5 \mathrm{~B})$. In addition, the oxidative impairment of neurons was 

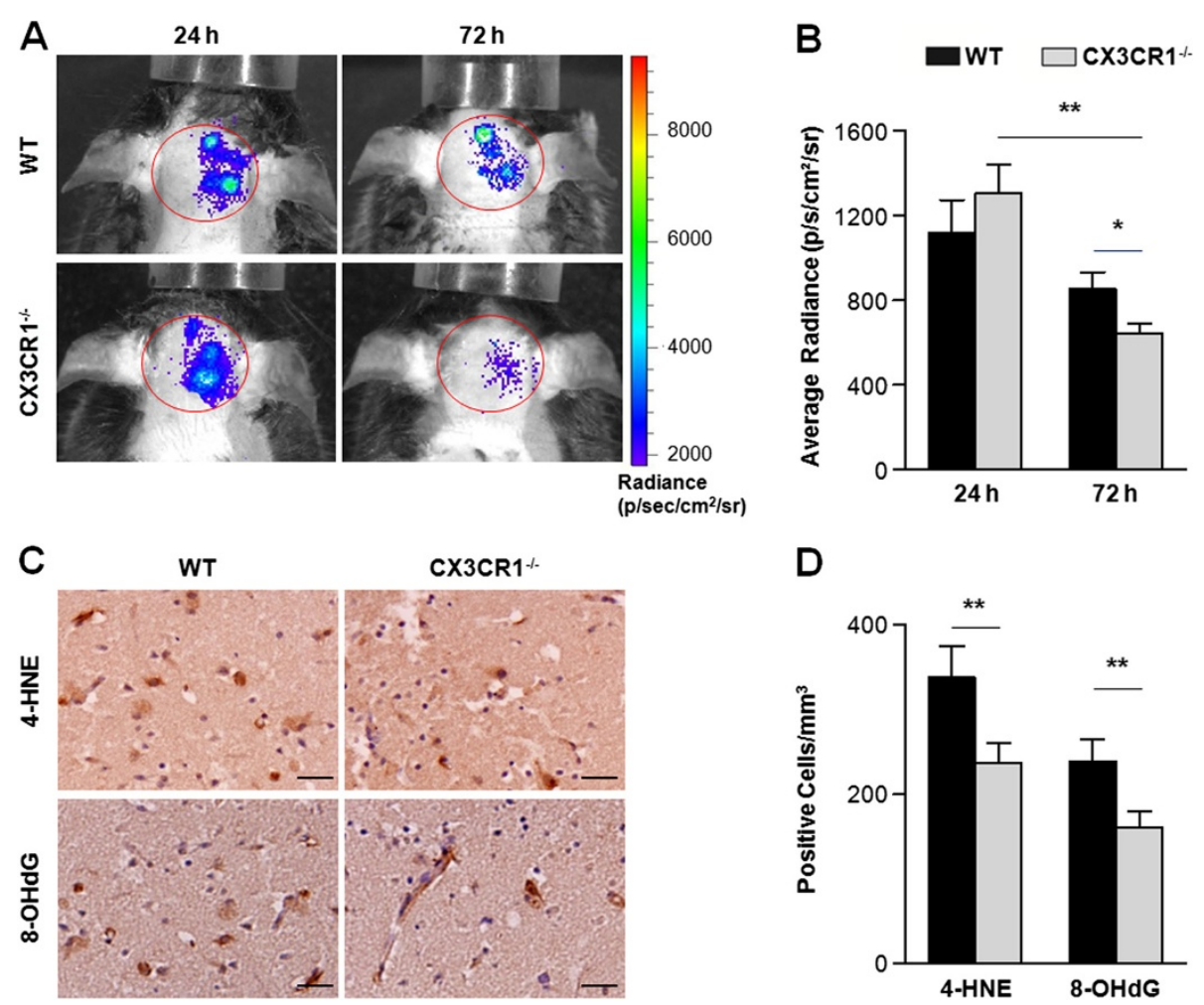

Figure 5 CX3CR1 deficiency attenuates reactive oxygen species generation in brain after middle cerebral artery occlusion. (A) Reactive oxygen species (ROS) were evaluated by Xenogen IVIS200 imager in wild-type (WT) and CX3CR1 ${ }^{-1-}$ mice in vivo. (B) Quantification of ROS. No difference in ROS levels were observed between the two groups 24 hours after MCAO. ROS level decreased in CX3CR1 ${ }^{-/-}$mice 72 hours after MCAO compared to 24 hours ( $P<0.0001$ for genotype and time point, $P=0.0036$ for interaction by two-way analysis of variance; ${ }^{* *} P<0.01$ by Bonferroni post-hoc tests) and is significantly less in $C X 3 \mathrm{CR}^{-/-}$mice relative to WT mice ${ }^{*} P<0.05$ by Bonferroni post-hoc tests). $n=6$ per group. $\mathrm{p} / \mathrm{s} / \mathrm{cm}^{2} / \mathrm{sr}$, photons per second per centimeter squared per steradian. (C) Immunohistochemistry for 4-hydroxy-2-nonenal (4-HNE) and 8-hydroxy-2-deoxyguanosine (8-OHdG) in the ischemic lesion 24 and 72 hours after MCAO. (D) Reduction of the number of stained cells in the CX3CR1 ${ }^{-1-}$ mice compared with WT mice. $P<0.0001$ for genotype, $P=0.0003$ for oxidative marker, and $P=0.9827$ for interaction by two-way analysis of variance. ${ }^{* *} P<0.01$ by Bonferroni post-hoc tests. $n=5$ per group scale bars: $50 \mu \mathrm{m}$.

immunohistochemically assessed by stain for lipid peroxidation with 4-HNE and damaged DNA with 8-OHdG (Figure 5C). The number of stained cells in the CX3CR1 $1^{-1-}$ mice was notably less compared with WT mice $(P<0.01)$ (Figure 5D).

\section{CX3CR1 deficiency impairs inflammatory signaling in microglia and macrophage in ischemic brain}

To determine whether CX3CR1 deficiency is associated with changes in the expression of inflammatory mediators produced by activated macrophages and microglia, ELISA was used to screen injured brain homogenates for differences in cytokine production. Consistent with previous reports [25-27], expression of a subset of inflammatory cytokines (IL-1 $\beta$, IL-6, and TNF- $\alpha$ ) was increased after MCAO regardless of genotype. In WT mice, the amounts of IL- $1 \beta$, IL- 6 , and TNF- $\alpha$ were $160.9 \pm 8.4,56.5 \pm 6.1,253.0 \pm 22.9 \mathrm{pg} / \mathrm{mg}$ in the ipsilateral hemisphere and $80.7 \pm 4.1,19.2 \pm 2.2,101.9 \pm$ $15.3 \mathrm{pg} / \mathrm{mg}$ in the contralateral hemisphere, respectively.
In CX3CR $1^{-1-}$ mice, the amounts of IL- $1 \beta$, IL- 6 , and TNF- $\alpha$ were $94.2 \pm 11.9,29.0 \pm 5.1,191.9 \pm 19.8 \mathrm{pg} / \mathrm{mg}$ in the ipsilateral hemisphere and $74.5 \pm 5.1,15.5 \pm 1.1$, $116.5 \pm 13.7 \mathrm{pg} / \mathrm{mg}$ in the contralateral hemisphere, respectively. Notably, post-injury expressions of these cytokines were markedly reduced in $\mathrm{CX} 3 \mathrm{CR}^{-1-}$ mice in the ipsilateral hemisphere, while no difference was observed in the contralateral hemisphere (Figure 6A).

To determine whether deficient CX3CR1 signaling in CNS microglia/macrophages could account for these cytokine expression changes, a series of controlled ex vivo flow cytometry assays were performed. Microglia and macrophages were isolated from ischemic brains of WT and CX3CR1 $1^{-1-}$ mice, followed by quantification of $\mathrm{IL}-1 \beta^{+} / \mathrm{CD} 11 \mathrm{~b}^{+} / \mathrm{Ly} 6 \mathrm{G}^{-}, \mathrm{IL}^{-} 6^{+} / \mathrm{CD} 11 \mathrm{~b}^{+} / \mathrm{Ly} 6 \mathrm{G}^{-}$, and TNF$\alpha^{+} / \mathrm{CD}_{11} \mathrm{~b}^{+} / \mathrm{Ly} 6 \mathrm{G}^{-}$cells using flow cytometry. Using this approach, an increased expression of IL-1 $\beta$, IL-6, and TNF- $\alpha$ in CD11b ${ }^{+}$Ly6G $^{-}$cells (fluorescent intensity in Figure 6B) as well as the numbers of cytokine-expressing

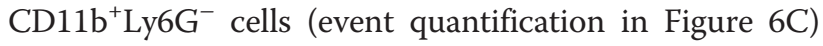




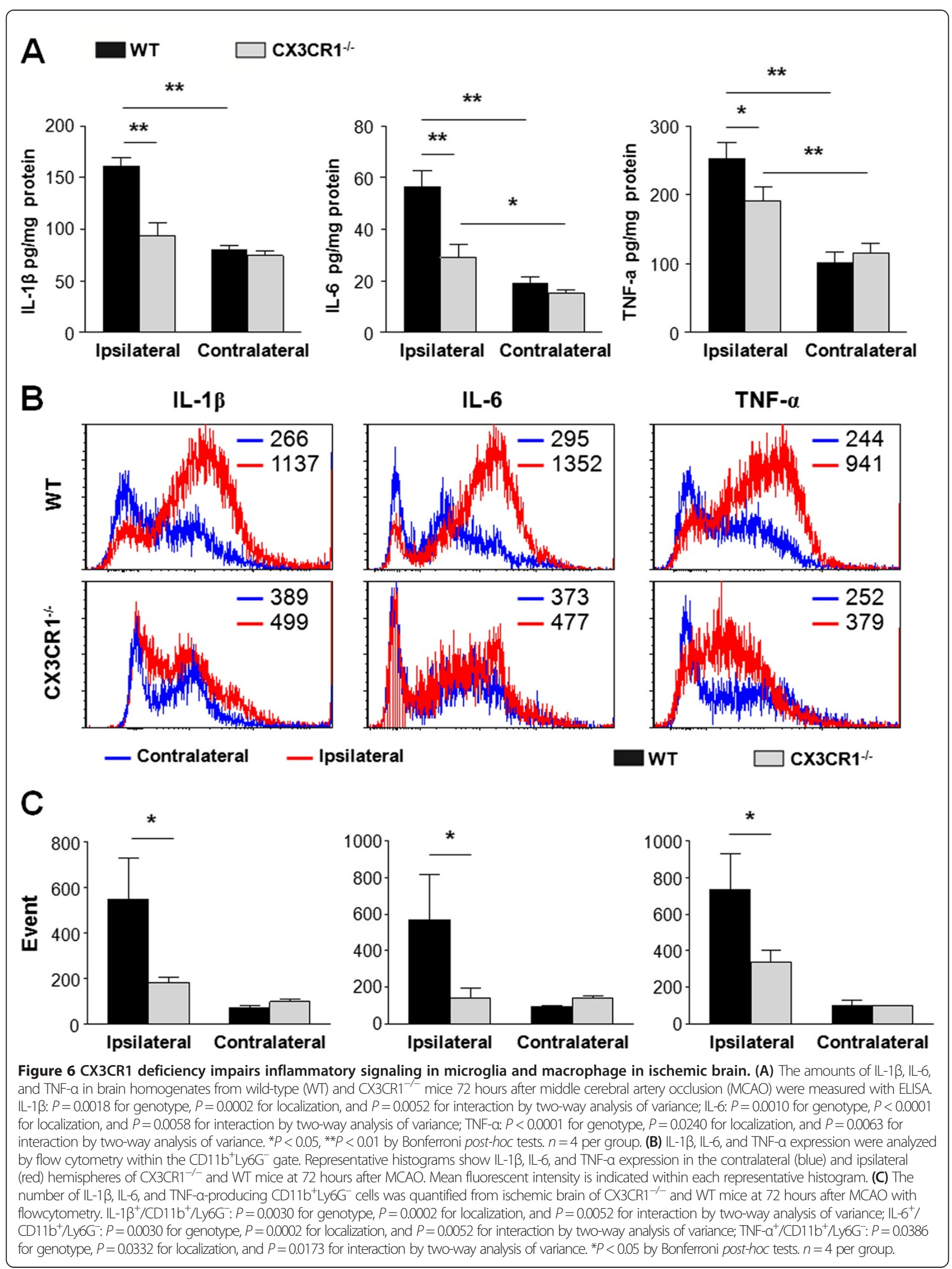


were detected 72 hours after MCAO in the ischemic lesions in WT mice (ipsilateral vs contralateral). This response was noticeably absent from the injured brain of $\mathrm{CX} 3 \mathrm{CR} 1^{-/-}$mice (Figure 6B,C). In the ipsilateral hemisphere, $\mathrm{CX} 3 \mathrm{CR} 1^{-/-}$mice displayed significant reduction in expression of IL-1 $\beta$, IL-6, and TNF- $\alpha$ in CD $11 b^{+}{\text {Ly } 6 G^{-}}^{-}$cells and cytokine-expressing $\mathrm{CD} 11 \mathrm{~b}^{+} \mathrm{Ly}_{6 \mathrm{G}^{-}}$cell numbers $(P<0.05$ vs WT, Figure 6B,C).

\section{Discussion}

The work presented here provides important in vivo evidence for the role of the CX3CL1/CX3CR1 signaling pathway in the activation and neurotoxicity of microglia/ macrophage in cerebral ischemia. Using $\mathrm{CX} 3 \mathrm{CR} 1^{-/-}$ mice, in which the CX3CR1 gene is substituted with the gene for the GFP on both alleles (CX3CR1 $\left.1^{\mathrm{GFP} / \mathrm{GFP}}\right)$, and a murine model of transient brain ischemia, we find that CX3CR1 deficiency resulted in a decrease in the size of ischemic lesion, a decrease in the number of apoptotic cells (predominantly neurons), marked deregulation of post-ischemic brain inflammatory responses (including ROS and pro-inflammatory cytokines), a significant decrease in proliferation of microglia and infiltrating macrophages in the ischemic lesion, and a marked decrease in the levels of IL-1 $\beta / \mathrm{IL}-6 / \mathrm{TNF}-\alpha$ expressed by microglia/macrophage in ischemic brain. Collectively, these effects due to CX3CR1 deficiency correlate with improved neurological function following $\mathrm{MCAO}$ and suggest that blockade of CX3CR1/CX3CL1 signaling may provide neuroprotection against ischemic injury.

Absence of fractalkine receptor in $\mathrm{CX} 3 \mathrm{CR} 1^{-/-}$mice has been previously reported to be protective in ischemia. Critically, significantly smaller (56\%) infarcts and blood-brain barrier damage have been observed in CX3CR1 $1^{-/-}$animals compared with CX3CR1 $1^{+/-}$and WT mice 72 hours after a 60-minute MCAO [15]. CX3CR1 deficiency has also been shown to induce protection from a 30-minute MCAO starting as early as 24 hours [17]. In an experimental model of spinal cord injury, CX3CR $1^{-/-}$mice demonstrate neuroprotection and functional recovery 5 days post-injury [16]. In agreement with these previous studies on the role of the CX3CL1/CX3CR1 pathway in acute CNS injury, our work finds that mice lacking CX3CR1 are protected from ischemic injury 72 hours after a 90-minute MCAO. Interestingly, we find prevention of exacerbation of ischemic lesion was accompanied with reduced cleaved Caspase 3 positive neurons in the peri-infarct area at 72 hours after initial stroke in CX3CR1 $1^{-/-}$mice compared to WT mice, inconsistent with a previous report [15]. While these observed differences could be attributed to the differences in the experimental designs, the outcomes between our study and others are identical. Further, it may also imply that the effects of CX3CL1/CX3CR1 signaling may be dependent upon the context of the specific disease state.
CX3CR1 deficiency has been suggested to attenuate tissue damage and improve recovery of function by reducing the recruitment and/or the activation of microglia and macrophages [15,28-30]. We tested this hypothesis by isolating mononuclear cells from the injured brain of WT and CX3CR1 $1^{-/-}$mice, followed by quantifying $\mathrm{CD} 45^{+} / \mathrm{CD} 11 \mathrm{~b}^{+}$cells by flow cytometry. We find a significant decrease in $\mathrm{CD}_{4} 5^{+} / \mathrm{CD}_{11 \mathrm{~b}}{ }^{+} / \mathrm{Ly} 6 \mathrm{G}^{-}$ microglia/macrophage in the ipsilateral hemisphere of $\mathrm{CX}_{3} \mathrm{CR} 1^{-/-}$mice vs WT mice, which was confirmed by immunohistochemical staining with Iba-1 in brain sections. To determine whether this was a result of suppressed microglia proliferation or decreased monocyte recruitment, the relative expression of CD45 has been used to differentiate resident microglia $\left(\mathrm{CD} 45^{\text {low }}\right)$ from recruited monocytes $\left(\mathrm{CD} 45^{\mathrm{hi}}\right)$ [31]. CD $45^{\text {low }} / \mathrm{CD} 11 \mathrm{~b}^{+} /$ Ly6G ${ }^{-}$cells (microglia) predominate in the contralateral side of both genotypes. However, by 72 hours postinjury, accumulation of both $\mathrm{CD} 45^{\text {low }}$ (microglia) and $\mathrm{CD}_{4} 5^{\mathrm{hi}}$ (macrophage/activated microglia) $\mathrm{CD} 11 \mathrm{~b}^{+} /$ Ly6G ${ }^{-}$cells dramatically decreased in the ischemic hemisphere of $\mathrm{CX} 3 \mathrm{CR} 1^{-/-}$mice. Moreover, BrdU assays show that the proliferation of microglia $\left(\mathrm{CD} 45^{\text {low }}\right)$ is significantly impaired in $\mathrm{CX} 3 \mathrm{CR} 1^{-1-} \mathrm{MCAO}$ mice. The proliferation of $\mathrm{CD} 45^{\mathrm{hi}}$ cells (including activated microglia) was also suppressed; however, not to the extent which could fully compensate for the decreased number of $\mathrm{CD} 45^{\text {hi }}$ cells seen in CX3CR $1^{-/-}$MCAO mice compared to WT MCAO mice. We therefore speculate that the migration of monocyte-derived macrophages from the periphery was inhibited. These data together indicate that both microglia/macrophage proliferation and macrophage recruitment are attenuated by CX3CR1 deficiency within the MCAO model. Our results coincide with a previous study that demonstrated decreased leukocytes infiltration as a possible mechanism for the development of smaller infarcts in CX3CR $1^{-/-}$mice after a 60-minute MCAO [15]. Conversely, more CD45 ${ }^{\text {hi }}$ cells were found accumulated in the injured spinal cords of $\mathrm{CX} 3 \mathrm{CR} 1^{-/-}$mice. Although the role of this cell population is not clear (rather, this study revealed a distinct monocyte subset), CD $11 \mathrm{~b}^{+} / \mathrm{Ly}_{6} \mathrm{C}^{\mathrm{lo}} / \mathrm{iNOS}^{+}$macrophages were associated with reduced neuropathology and enhanced functional recovery [16]. Indeed, it has long been thought that macrophage (microglia) are not a uniform cell population, such that specific environmental signals, including effector molecules, timing of activation, and degree of injury, may induce their different polarization states [32,33]. Therefore, phenotypically distinct monocyte populations appear to be associated with tissue pathology and repair in ischemia and, thus, warrant further study [16].

Previous reports indicated a marked increase in proinflammatory cytokine levels that peak 12 to 24 hours after 
ischemic injury [34]. Our results obtained from the WT mice are in agreement with these temporal dynamics of cytokines. As expected, an initial increase of TNF- $\alpha$, IL$1 \beta$, and IL- 6 was detected in the ipsilateral hemisphere after MCAO. However, contrary to the levels of proinflammatory cytokines observed in control samples, we show that the ablation of proliferating microglia cells and recruitment of monocytes, associated with CX3CR1 deficiency, resulted in a significant decrease in the levels of IL- $1 \beta$, TNF- $\alpha$, and IL-6, suggesting an important temporal deregulation of the proinflammatory cytokine response. Similar patterns of mRNA expression and temporal deregulations were observed in the NF- $\mathrm{kB}$ signaling pathway, a general marker of inflammatory response in cerebral ischemia [16]. Furthermore, using flow cytometry, we confirmed that the trends of proinflammatory cytokines in the ipsilateral hemisphere of the MCAO brain in CX3CR1 $1^{-1-}$ mice are consistent with the levels secreted by CX3CR1 $1^{-1-}$ microglia/macrophage isolated from MCAO brains. Therefore, it appears that microglia/macrophage may play an important role in the regulation/modulation of the proinflammatory responses in cerebral ischemia, and their functions are attenuated by CX3CR1 deficiency.

Variations of cell morphology or cell displacement are related to the specific activity of microglia/macrophage [32]. Following ischemia, activated microglia/macrophage can potentially exert either a protective or detrimental effect, suggesting that these cells may acquire different phenotypes belonging to the classical (M1) or to the alternative (M2) active status [35]. M1 activation is generally referred to as the pro-inflammatory and cytotoxic phenotype, characterized by nitric oxide, ROS, and proinflammatory cytokine production, while the M2 phenotype is an alternative activation state, associated with a fine tuning of inflammation, scavenging of debris, promotion of angiogenesis, tissue remodeling and repair $[17,36]$. Fumagalli and colleagues [17] reported that, in CX3CR1 $1^{-/-}$ mice, protection from ischemia at early time points after injury is associated with a protective inflammatory milieu, characterized by the promotion of M2 polarization markers. We found that activated M1-like Iba- $1^{+}$cells, which have shorter and thicker processes and bigger cell bodies, were visualized in the WT brain section, while ramified M2-like Iba- $1^{+}$cells were predominantly located in the CX3CR1 $1^{-1-}$ brain (Figure 3A) with increased expression of M2 markers (Figure 3E), implying that suppressed activation of microglia/macrophage by CX3CR1 deficiency may be responsible for the neuroprotective effects in the CX3CR $1^{-/-}$mice.

\section{Conclusion}

In summary, using a murine model of transient focal ischemia, we explored the consequences of CX3CR1 absence on microglia/macrophage proliferation/recruitment and on their activation after brain ischemia. When CX3CR1 signaling is abolished, neurological recovery is improved and neural pathology is reduced. Our data show that loss of CX3CR1 signaling attenuates the proliferation and inflammatory capacity of microglia/macrophages. Moreover, monocytes recruitment and/or the differentiation of newly recruited monocyte subsets are altered. Collectively, these data identify CX3CR1 as a putative therapeutic target for selectively reducing neurodestructive inflammatory cascades after stroke.

\section{Additional file}

Additional file 1: Supplemental Methods and Figures.

\section{Abbreviations}

4-HNE: 4-hydroxy-2-nonenal; 8-OHdG: 8-hydroxy-2-deoxyguanosine;

ADC: apparent diffusion coefficient; BrdU: 5-bromo-2-deoxyuridine;

CBF: cerebral blood flow; CNS: central nervous system; CX3CL1: chemokine (C-X3-C motif) ligand 1; CX3CR1: CX3C chemokine receptor 1; CX3CR1 ${ }^{-1-}$ : CX3CR1-deficient; ELISA: enzyme-linked immunosorbent assay; FACS: Fluorescence Activated Cell Sorter; GFP: green fluorescent protein; LL: interleukin; MCAO: middle cerebral artery occlusion; MRl: magnetic resonance imaging; PBS: phosphate-buffered saline; PCR: polymerase chain reaction; ROS: reactive oxygen species; TNF: tumor necrosis factor; TTC: 2,3,5-triphenyltetrazolium chloride; WT: wild-type.

\section{Competing interests}

The authors declare that they have no competing interests.

\section{Authors' contribution}

ZT and YG designed the experiments. ZT, YG, QL, J-XY and QL performed the experiments. ZT and YG analyzed the data and wrote the paper. JS and F-DS supervised the experimental work. F-DS obtained the funding and resources. All authors read and approved the final manuscript.

\section{Acknowledgments}

The authors thank Drs P Han, L Inge, A Simard, and A Kousari for their technical and editorial assistance. This study was supported in part by the National Basic Science Program of China (2013CB966900), National Natural Science Foundation of China (81230028 and 81360204), National Key Project of Clinical Neurology of China, US National Institutes of Health (R01A1083294, R01NS082745 and R21NS082902) and the American Heart Association (GRNT18970031).

\section{Author details}

'Department of Neurology and the BNI-ASU Center for Preclinical Imaging, Barrow Neurological Institute, St. Joseph's Hospital and Medical Center, 350 West Thomas Road, Phoenix, Arizona 85013, USA. ²Department of Neurology, Key Laboratory of Neurorepair and Regeneration, Tianjin and Ministry of Education and Tianjin Neurological Institute, Tianjin Medical University General Hospital, Tianjin 300052, China. ${ }^{3}$ Department of Neurosurgery, the First Affiliated Hospital of Kunming Medical University, Kunming 650031, China.

Received: 1 August 2013 Accepted: 13 January 2014

Published: 3 February 2014

\section{References}

1. Kigerl KA, Gensel JC, Ankeny DP, Alexander JK, Donnelly DJ, Popovich PG: Identification of two distinct macrophage subsets with divergent effects causing either neurotoxicity or regeneration in the injured mouse spinal cord. J Neurosci 2009, 29:13435-13444.

2. Zujovic V, Benavides J, Vige X, Carter C, Taupin V: Fractalkine modulates TNF-alpha secretion and neurotoxicity induced by microglial activation. Glia 2000, 29:305-315. 
3. Mizuno T, Kawanokuchi J, Numata K, Suzumura A: Production and neuroprotective functions of fractalkine in the central nervous system. Brain Res 2003, 979:65-70.

4. Bazan JF, Bacon KB, Hardiman G, Wang W, Soo K, Rossi D, Greaves DR, Zlotnik A, Schall TJ: A new class of membrane-bound chemokine with a CX3C motif. Nature 1997, 385:640-644.

5. Nishiyori A, Minami M, Ohtani Y, Takami S, Yamamoto J, Kawaguchi N, Kume T, Akaike A, Satoh M: Localization of fractalkine and CX3CR1 mRNAs in rat brain: does fractalkine play a role in signaling from neuron to microglia? FEBS Lett 1998, 429:167-172.

6. Harrison JK, Jiang Y, Chen S, Xia Y, Maciejewski D, McNamara RK, Streit WJ, Salafranca MN, Adhikari S, Thompson DA, Botti P, Bacon KB, Feng L: Role for neuronally derived fractalkine in mediating interactions between neurons and CX3CR1-expressing microglia. Proc Natl Acad Sci U S A 1998 95:10896-10901

7. Prinz M, Priller J: Tickets to the brain: role of CCR2 and CX3CR1 in myeloid cell entry in the CNS. J Neuroimmunol 2010, 224:80-84.

8. Imai T, Hieshima K, Haskell C, Baba M, Nagira M, Nishimura M, Kakizaki M, Takagi S, Nomiyama H, Schall TJ, Yoshie O: Identification and molecular characterization of fractalkine receptor CX3CR1, which mediates both leukocyte migration and adhesion. Cell 1997, 91:521-530.

9. Fong AM, Robinson LA, Steeber DA, Tedder TF, Yoshie O, Imai T, Patel DD Fractalkine and CX3CR1 mediate a novel mechanism of leukocyte capture, firm adhesion, and activation under physiologic flow. J Exp Med 1998, 188:1413-1419.

10. Fuhrmann M, Bittner T, Jung CK, Burgold S, Page RM, Mitteregger G, Haass C, LaFerla FM, Kretzschmar H, Herms J: Microglial Cx3cr1 knockout prevents neuron loss in a mouse model of Alzheimer's disease. Nat Neurosci 2010, 13:411-413.

11. Liu Z, Condello C, Schain A, Harb R, Grutzendler J: CX3CR1 in microglia regulates brain amyloid deposition through selective protofibrillar amyloid-beta phagocytosis. J Neurosci 2010, 30:17091-17101.

12. Cardona AE, Pioro EP, Sasse ME, Kostenko V, Cardona SM, Dijkstra IM, Huang D, Kidd G, Dombrowski S, Dutta R, Lee JC, Cook DN, Jung S, Lira SA, Littman DR, Ransohoff RM: Control of microglial neurotoxicity by the fractalkine receptor. Nat Neurosci 2006, 9:917-924.

13. Jung S, Aliberti J, Graemmel P, Sunshine MJ, Kreutzberg GW, Sher A, Littman DR: Analysis of fractalkine receptor CX(3)CR1 function by targeted deletion and green fluorescent protein reporter gene insertion. Mol Cell Biol 2000, 20:4106-4114.

14. Davalos D, Grutzendler J, Yang G, Kim JV, Zuo Y, Jung S, Littman DR, Dustin ML, Gan WB: ATP mediates rapid microglial response to local brain injury in vivo. Nat Neurosci 2005, 8:752-758.

15. Denes A, Ferenczi S, Halasz J, Kornyei Z, Kovacs KJ: Role of CX3CR1 (fractalkine receptor) in brain damage and inflammation induced by focal cerebral ischemia in mouse. J Cereb Blood Flow Metab 2008, 28:1707-1721.

16. Donnelly DJ, Longbrake EE, Shawler TM, Kigerl KA, Lai W, Tovar CA, Ransohoff RM, Popovich PG: Deficient CX3CR1 signaling promotes recovery after mouse spinal cord injury by limiting the recruitment and activation of Ly6Clo/iNOS + macrophages. J Neurosci 2011, 31:9910-9922.

17. Fumagalli S, Perego C, Ortolano F, De Simoni MG: CX3CR1 deficiency induces an early protective inflammatory environment in ischemic mice. Glia 2013, 61:827-842.

18. Liesz A, Suri-Payer E, Veltkamp C, Doerr H, Sommer C, Rivest S, Giese T, Veltkamp R: Regulatory T cells are key cerebroprotective immunomodulators in acute experimental stroke. Nat Med 2009, 15:192-199.

19. Chen J, Zacharek A, Zhang C, Jiang H, Li Y, Roberts C, Lu M, Kapke A, Chopp $M$ : Endothelial nitric oxide synthase regulates brain-derived neurotrophic factor expression and neurogenesis after stroke in mice. J Neurosci 2005, 25:2366-2375.

20. Tureyen K, Vemuganti R, Sailor KA, Dempsey RJ: Infarct volume quantification in mouse focal cerebral ischemia: a comparison of triphenyltetrazolium chloride and cresyl violet staining techniques. J Neurosci Methods 2004, 139:203-207.

21. Real-time bioluminescence imaging of myeloperoxidase activity in small laboratory animals. [http://www.nature.com/protocolexchange/protocols/ 526\#/procedure]

22. Bai XF, Li O, Zhou Q, Zhang H, Joshi PS, Zheng $X$, Liu Y, Wang Y, Zheng $P$ : CD24 controls expansion and persistence of autoreactive T cells in the central nervous system during experimental autoimmune encephalomyelitis. J Exp Med 2004, 200:447-458.
23. Cardona $A E$, Huang $D$, Sasse ME, Ransohoff RM: Isolation of murine microglial cells for RNA analysis or flow cytometry. Nat Protoc 2006, 1:1947-1951.

24. Hao J, Liu R, Piao W, Zhou Q, Vollmer TL, Campagnolo DI, Xiang R, La Cava A, Van Kaer L, Shi FD: Central nervous system (CNS)-resident natural killer cells suppress Th17 responses and CNS autoimmune pathology. J Exp Med 2010, 207:1907-1921

25. Pineau I, Lacroix S: Proinflammatory cytokine synthesis in the injured mouse spinal cord: multiphasic expression pattern and identification of the cell types involved. J Comp Neurol 2007, 500:267-285.

26. Muir KW, Tyrrell P, Sattar N, Warburton E: Inflammation and ischaemic stroke. Curr Opin Neurol 2007, 20:334-342

27. Lambertsen $\mathrm{KL}$, Biber $\mathrm{K}$, Finsen B: Inflammatory cytokines in experimental and human stroke. J Cereb Blood Flow Metab 2012, 32:1677-1698.

28. Lesnik P, Haskell CA, Charo IF: Decreased atherosclerosis in CX3CR1 ${ }^{-1-}$ mice reveals a role for fractalkine in atherogenesis. J Clin Invest 2003, 111:333-340.

29. Nanki T, Urasaki Y, Imai T, Nishimura M, Muramoto K, Kubota T, Miyasaka N: Inhibition of fractalkine ameliorates murine collagen-induced arthritis. J Immunol 2004, 173:7010-7016.

30. Oh DJ, Dursun B, He Z, Lu L, Hoke TS, Ljubanovic D, Faubel S, Edelstein CL: Fractalkine receptor (CX3CR1) inhibition is protective against ischemic acute renal failure in mice. Am J Physiol Renal Physiol 2008, 294:F264-F271.

31. Sedgwick JD, Schwender S, Imrich H, Dorries R, Butcher GW, ter Meulen V: Isolation and direct characterization of resident microglial cells from the normal and inflamed central nervous system. Proc Natl Acad Sci U S A 1991, 88:7438-7442.

32. Porta C, Rimoldi M, Raes G, Brys L, Ghezzi P, Di Liberto D, Dieli F, Ghisletti S, Natoli G, De Baetselier P, Mantovani A, Sica A: Tolerance and M2 (alternative) macrophage polarization are related processes orchestrated by $\mathrm{p} 50$ nuclear factor kappaB. Proc Natl Acad Sci U S A 2009, 106:14978-14983.

33. Zanier ER, Montinaro M, Vigano M, Villa P, Fumagalli S, Pischiutta F, Longhi L, Leoni ML, Rebulla P, Stocchetti N, Lazzari L, De Simoni MG: Human umbilical cord blood mesenchymal stem cells protect mice brain after trauma. Crit Care Med 2011, 39:2501-2510.

34. Devalaraja MN, McClain CJ, Barve S, Vaddi K, Hill DB: Increased monocyte MCP-1 production in acute alcoholic hepatitis. Cytokine 1999, 11:875-881.

35. David S, Kroner A: Repertoire of microglial and macrophage responses after spinal cord injury. Nat Rev Neurosci 2011, 12:388-399.

36. Michelucci A, Heurtaux T, Grandbarbe L, Morga E, Heuschling P. Characterization of the microglial phenotype under specific pro-inflammatory and anti-inflammatory conditions: effects of oligomeric and fibrillar amyloid-beta. J Neuroimmunol 2009, 210:3-12.

\section{doi:10.1186/1742-2094-11-26}

Cite this article as: Tang et al:: CX3CR1 deficiency suppresses activation and neurotoxicity of microglia/macrophage in experimental ischemic stroke. Journal of Neuroinflammation 2014 11:26.

\section{Submit your next manuscript to BioMed Central and take full advantage of:}

- Convenient online submission

- Thorough peer review

- No space constraints or color figure charges

- Immediate publication on acceptance

- Inclusion in PubMed, CAS, Scopus and Google Scholar

- Research which is freely available for redistribution 